\title{
PENINGKATAN HASIL BELAJAR IPA MELALUI MODEL PEMBELAJARAN DISCOVERY LEARNING PADA PESERTA DIDIK DI SMPN 2 KOTA BEKASI
}

\author{
Ngadiwon \\ SMP Negeri 2 Kota Bekasi, Indonesia \\ ngadiwonm@gmail.com
}

\begin{abstract}
Received: 18 September 2020 Penelitian ini dilatarbelakangi oleh rendahnya hasil belajar pokok Materi Revised: 21 September 2020 Sel Sebagai Unit Struktural Dan Fungsional peserta didik kelas VII-6 SMP Accepted: 04 Oktober 2020 Negeri 2 Kota Bekasi. Berdasarkan hasil observasi, penyebab rendahnya hasil belajar peserta didik ialah masih menggunakan model konvensional, kurangnya referensi sumber belajar, pembelajaran masih berpusat pada guru, kurangnya antusias peserta didik dalam proses pembelajaran. Untuk memperbaiki permasalahan tersebut sehingga terjadi peningkatan hasil belajar peserta didik maka dilakukan pembelajaran dengan menggunakan model pembelajaran Discovery Learning. Jenis penelitian ini menggunakan penelitian tindakan kelas (PTK). Model desain penelitian tindakan yang digunakan yaitu Kemmis dan MC Taggart. Pada penelitian ini instrumen pengambilan data menggunakan soal tes dan lembar observasi. Teknik analisis data menggunakan teknik deskriptif komparatif antar siklus dan deskripsi ketuntasan hasil belajar. Dari hasil penelitian yang sudah dilakukan ditemukan hasil bahwa pembelajaran dengan menggunakan model pembelajaran Discovery Learning dapat meningkatkan hasil belajar peserta didik. Hal ini dibuktikan dengan persentase peningkatan hasil belajar peserta didik mencapai ketuntasan, terlihat peningkatan terjadi pada siklus I dari kondisi awal 16 peserta didik $(65,60 \%)$ yang tuntas menjadi 26 peserta didik $(73,53 \%)$ yang tuntas. Peningkatan pada siklus II menjadi 35 peserta didik $(85,36 \%)$ yang tuntas. Saran yang dapat penulis ajukan dengan penelitian ini ialah guru dapat menggunakan Model pembelajaran Discovery Learning sebagai model pembelajaran untuk meningkatkan hasil belajar peserta didik.

Keywords: Hasil Belajar; IPA; Materi Sel; Discovery Learning
\end{abstract}

(*) Corresponding Author: $\quad$ Ngadiwon, ngadiwonm@gmail.com

How to Cite: Ngadiwon. (2020). Peningkatan Hasil Belajar IPA Melalui Model Pembelajaran Discovery Learning Pada Peserta Didik Di SMPN 2 Kota Bekasi. Research and Development Journal of Education, $1(1), 117-130$.

\section{INTRODUCTION}

Berdasarkan hasil observasi yang dilakukan di kelas VII-6 SMP Negeri 2 Kota Bekasi semester 1 Tahun ajaran 2017/2018 ditemukan bahwa dalam kegiatan pembelajaran yang dilakukan, guru kurang terencana dalam menyiapkan pembelajaran. Guru juga sering lupa menyampaikan tujuan dari pembelajaran dan memonopoli proses pembelajaran yang dilakukan. Materi pembelajaran yang disampaikan guru bersumber dari buku tema (buku pegangan guru dan pegangan peserta didik) saja, pertukaran informasi yang bersumber dari guru hanya bersifat informatif tanpa adanya pemahaman yang mendalam dari peserta didik.

Dengan kurangnya pemahaman akan model-model pembelajaran, guru hanya menggunakan model konvensional yang dimana guru hanya menggunakan metode 
ceramah dalam menyampaikan materi pembelajaran (Vhalery, 2019), peserta didik hanya diminta mendengarkan dan mencatat materi yang diberikan oleh guru, sehingga guru yang mendominasi dalam pembelajaran, sedangkan peserta didik cenderung pasif dan berbicara sendiri dengan temannya.

Dengan tingkat pemahaman yang rendah maka akan berdampak pada hasil akhir belajar peserta didik tidak maksimal. Hal ini terlihat dari hasil tes 41 peserta didik bahwa 25 peserta didik $(60,97 \%)$ belum memenuhi batas ketuntasan pada standar KKM, dan peserta didik yang sudah tuntas sesuai standar KKM ialah 16 peserta didik $(39,02 \%)$. Hasil belajar peserta didik yang rendah tidak lepas dari pengaruh guru dalam penyampaian materi pembelajaran. Maka dari itu, desain pembelajaran yang baik dengan menggunakan model yang sesuai karakter peserta didik penting untuk dilakukan.

Rendahnya hasil belajar peserta didik akibat kurang aktifnya dari kegiatan peserta didik saat kegiatan pembelajaran berlangsung. Dengan model pembelajaran yang konvensional, peserta didik menjadi cepat bosan dalam mengikuti pembelajaran. Seringkali peserta didik meminta izin untuk pergi ke toilet secara bergantian. Bahkan banyak peserta didik yang lebih memilih untuk bermain bersama temannya saat kegiatan belajar berlangsung, tak jarang mereka mencari perhatian dengan membuat gaduh suasana kelas. Hal ini akan berdampak pada pemahaman peserta didik terhadap materi pembelajaran dan mempengaruhi hasil belajar mereka.

Berdasarkan permasalahan yang ada di atas, penelitian ini akan mencoba inovasi baru dalam pembelajaran sebagai upaya untuk meningkatkan hasil belajar dan mengembangkan psikomotorik peserta didik untuk berfikir lebih luas pada pembelajaran IPA di kelas VII-6 SMP Negeri 2 Kota Bekasi. Inovasi pembelajaran yang akan dilakukan ialah dengan menerapkan model pembelajaran Discovery Learning. Berdasarkan uraian masalah, rumusan masalah yaitu Apakah penggunaan model pembelajaran Discovery Learning dapat meningkatkan hasil belajar mata pelajaran IPA?. Tujuan penelitian Mendiskripsikan peningkatan hasil belajar mata pelajaran IPA melalui penggunaan model pembelajaran Discovery Learning.

\section{LITERATURE REVIEW}

\section{Hakikat Belajar}

Menurut Slameto (2010 : 14) belajar ialah proses perubahan tingkah laku sebagai hasil interaksi dengan lingkungannya dalam memenuhi kebutuhan hidupnya serta perubahan-perubahan tersebut akan nyata dalam seluruh aspek kehidupan. Menurut Skiner (dalam Angkowo dan Kosasih, 2007 : 47) belajar ialah proses adaptasi dan penyesuaian tingkah laku yang berlangsung progresif. Bell Gredler (dalam Angkowo dan Kosasih, 2007 : 47) menyatakan bahwa belajar sebagai cara memperoleh berbagai kemampuan, ketrampilan dan sikap. Belajar ialah tahapan perubahan seluruh tingkah laku sesorang yang relatif menetap sebagai hasil pengalaman interaksi dengan lingkungan yang melibatkan proses kognitif. Angkowo dan Kosasih (2007 : 48) menyatakan belajar ialah perubahan persepsi dan pemahaman. Perubahan persepsi dan pemahaman ini tidak selalu terbentuk perubahan tingkah laku yang diamati. Kladen (dalam Angkowo dan Kosasih, 2007 : 48) menyatakan bahwa belajar berarti mempraktekkan, sedangkan belajar tentang sesuatu berarti mengetahui sesuatu. Cronbach (dalam Angkowo dan Kosasih, 2007 : 48) menyatakan arti belajar: "Learning is shown by a change is behavior as a result of experience" (pembelajaran ditunjukkan oleh perubahan perilaku sebagai hasil dari pengalaman). Harold Spears (dalam Angkowo dan Kosasih, 2007 : 48) menyatakan batasan tentang belajar : learning is to observe, to read, to imitate, to try something themselves, to listen, to follow direction" (belajar ialah mengamati, membaca, meniru, 
mencoba sesuatu sendiri, mendengarka dan mengikuti arah). Sedangkan Geoch (dalam Angkowo dan Kosasih, 2007 : 48) mengatakan: "learning is a change in performance as a result of practice"(belajar ialah perubahan dalam kinerja sebagai hasil dari latihan). Winkel (2014 : 21) menyatakan belajar ialah perubahan tingkah laku atau penampilan, dengan serangkaian kegiatan, misalnya mengamati, mendengarkan, membaca, dan meniru. Jadi, dari pengertian beberapa pendapat diatas dapat disimpulkan oleh peneliti bahwa belajar ialah suatu usaha yang dilakukan seseorang untuk memperoleh perubahan tingkah laku yang baru, sebagai hasil pengalamannya sendiri dalam interaksi dengan lingkungannya.

\section{Model Pembelajaran Discovery Learning}

Menurut Babbage, Byers \& Redding (1999) yang dikutip oleh Jamil Suprihatiningrum (2013 : 142), model pembelajaran didefinisikan sebagai berikut: (a) Sebagai landasan teori dan rincian tahapan dari teknik pembelajaran, (b) Sebuah filosofi yang mendikte pendekatan-pendekatan dan metode-metode dan biasanya ditampilkan dalam satu paket, dan (c) Sebuah penjelasan dari gaya mengajar dan ditampikan dalam praktik pengajaran, yang mana menjelaskan bagaimana peserta didik tersebut dibelajarkan. Suryobroto (2010:42) berpendapat bahwa discovery ialah proses mental dimana peserta didik mengasimilasikan sesuatu prinsip. Proses mental tersebut misalnya: membuat dugaan, mengamati, menggolong-golongkan, menjelaskan, mengukur, membuat kesimpulan dan sebagainya. Sedangkan menurut Bruner (dalam Markaban, 2006:9) penemuan ialah sebuah proses, sebuah jalan atau cara dalam mendekati permasalahan suatu produk atau item pengetahuan tertentu. Menurut pandangan Bruner, belajar dengan penemuan ialah belajar untuk menemukan, dimana seorang peserta didik dihadapkan dengan suatu masalah atau situasi yang tampaknya ganjil sehingga peserta didik dapat mencari jalan pemecahan. Mulyono (2015:221) berpendapat bahwa discovery learning menekankan kepada proses, mencari dan menemukan, dan materi pelajaran tidak diberikan secara langsung. Budiningsih (2012:43) berpendapat, model Discovery Learning ialah cara belajar memahami arti, konsep, dan hubungan melalui proses intuitif sampai kepada suatu kesimpulan. Dari beberapa pendapat tentang pengertian model Discovery Learning dapat disimpulkan bahwa model discovey learning ialah model mengajar yang mengatur pengajaran sedemikian rupa sehingga peserta didik mendapatkan pengetahuan yang sebelumnya belum diketahuinya itu tidak melalui pemberitahuan, sebagian atau keseluruhannya ditemukan sendiri.

Model Discovery Learning dari Bruner, merupakan model pembelajaran dan prinsip konstruktivis. Dengan model pembelajaran Discovery Learning peserta didik didorong untuk belajar secara mandiri. Peserta didik belajar aktif dengan konsep-konsep dan prinsip-prinsip dalam memecahkan masalah, dan guru mendorong peserta didik untuk mendapatkan pengalaman dengan melakukan kegiatan yang memungkinkan peserta didik menemukan prinsip-prinsip untuk diri mereka sendiri, bukan memberi tahu tetapi memberikan kesempatan atau dengan berdialog agar peserta didik menemukannya sendiri. Model pembelajaran ini membangkitkan keingintahuan peserta didik dan memotivasi peserta didik untuk bekerja sampai menemukan jawaban. Peserta didik belajar memecahkan masalah mereka sendiri dengan keterampilan berfikir untuk menganalisis dan memanipulasi informasi.

Menurut Suryobroto (2010:200) langkah-langkah model Discovery Learning ialah: 1) Mengidentifikasi kebutuhan peserta didik, 2) Memilih pendahuluan terhadap prinsipprinsip, pengertian, konsep yang akan dipelajari, 3) Memilih bahan dan masalah, 4) Membantu memperjelas masalah yang akan dipelajari peserta didik, 5) Mempersiapkan alat-alat yang akan digunakan dalam proses penemuan, 6) Memeriksa pemahaman peserta didik terhadap masalah yang akan dipecahkan, 7) Peserta didik diberikan kesempatan 
untuk melakukan penemuan, 8) Membantu peserta didik dengan informasi, data, jika diperlukan oleh peserta didik, 9) Mampu menganalisis secara mandiri dengan pertanyaan yang mengarahkan dan mengidentifikasi proses, 10) Menumbuhkan interaksi antar peserta didik dengan peserta didik lain, 11) Memuji peserta didik yang aktif dalam proses penemuan, 12) Mendorong peserta didik untuk merumuskan prinsip-prinsip dan generalisasi atas hasil penemuan.

\section{METHODS}

Penelitian Tindakan Kelas atau PTK ialah pendekatan yang digunakan oleh Peneliti. Sampel penelitian dan sumber data penelitian ini yaitu peserta didik kelas VII-6 di SMPN 2 Kota Bekasi Tahun Pelajaran 2017/2018 yang berjumlah 41 peserta didik. Kolaborator dalam penelitian ini yaitu teman sejawat di SMPN 2 Kota Bekasi yaitu guru IPA. Peneliti menggunakan teknik wawancara, observasi dan studi dokumentasi. Analisis data yang diajukan peneliti menggunakan analisis data deskriptif persentase.

\section{RESULTS \& DISCUSSION}

\section{Results}

\section{Siklus I}

Tindakan pembelajaran pada siklus I (satu) dilaksanakan dalam 4 tahap yaitu tahap perencanaan, tindakan, pengamatan, dan refleksi.

\section{a. Perencanaan (Planning)}

Peneliti menetapkan kolaborator, membuat jadwal pelaksanaan kegiatan yang telah disepakati antara praktikan, observer, dan anggota kelompok, menetapkan fasilitas layanan bimbingan kelompok berupa kelengkapan administrasi yaitu daftar hadir, lembar evaluasi, serta satuan layanan, dan menyiapkan intrumen pengumpulan data.

\section{b. Pelaksanaan (Action)}

Tahap pelaksanaan pada siklus I (satu) dilaksanakan sebanyak 3 (tiga) kali pertemuan.

\section{Pertemuan Pertama}

Kegiatan pendahuluan dilaksanakan dengan alokasi waktu 15 menit, diawali dengan guru memberi salam, guru mengajak peserta didik berdoa, guru melakukan absensi, guru mengecek tempat duduk peserta didik sudah rapi atau belum, kemudian guru melakukan apersepsi.

Kegiatan inti dilakukan dengan alokasi waktu kurang lebih 90 menit, diawali dengan Guru memberitahukan materi pelajaran yang akan dibahas, namun guru tidak menyampaikan tujuan pembelajaran yang akan disampaikan. Guru menayangkan gambar/foto tentang Sel. Peserta didik mengamati dengan seksama gambar/foto presentasi yang disajikan dan mencoba menginterprestasikannya. Berdasarkan hasil pengamatan terhadap gambar, peserta didik diminta untuk mendiskusikan tentang hal-hal yang ingin diketahui. Menyampaikan hasil diskusi berupa kesimpulan berdasarkan hasil analisis secara lisan, tertulis, atau media lainnya, dan mengungkapkan pendapat dengan sopan. 
Kegiatan penutup dilakukan dengan alokasi waktu 15 menit, dengan menarik kesimpulan hasil pembelajaran yang telah dilaksanakan dan menutup pembelajaran dengan do'a.

\section{Pertemuan Kedua}

Kegiatan pendahuluan dilaksanakan dengan alokasi waktu 15 menit, diawali dengan guru memberi salam, guru mengajak peserta didik berdoa, guru melakukan absensi, guru mengecek tempat duduk peserta didik sudah rapi atau belum, kemudian guru melakukan apersepsi.

Kegiatan inti dilakukan dengan alokasi waktu 90 menit, diawali dengan guru memberitahukan materi pelajaran yang akan dibahas namun guru kembali tidak menyampaikan tujuan pembelajaran yang akan disampaikan. Guru menayangkan gambar/foto tentang Sel. Peserta didik mengamati dengan seksama gambar/foto presentasi yang disajikan dan mencoba menginterprestasikannya. Berdasarkan hasil pengamatan terhadap gambar, peserta didik diminta untuk mendiskusikan tentang hal-hal yang ingin diketahui. Peserta didik menyampaikan hasil diskusi berupa kesimpulan berdasarkan hasil analisis secara lisan, tertulis, atau media lainnya. Peserta didik mempresentasikan hasil diskusi kelompok secara klasikal. Peserta didik mengemukakan pendapat atas presentasi yang dilakukan dan ditanggapi oleh kelompok yang mempresentasikan. Peserta didik bertanya atas presentasi yang dilakukan dan peserta didik lain diberi kesempatan untuk menjawabnya. Peserta didik menyimpulkan tentang poin-poin penting yang muncul dalam kegiatan pembelajaran yang baru dilakukan berupa : Laporan hasil pengamatan secara tertulis. Kegiatan penutup dilakukan dengan alokasi waktu 15 menit yaitu guru dan peserta didik menarik kesimpulan hasil pembelajaran yang telah dilaksanakan, guru memberikan soal evaluasi untuk mengukur keberhasilan belajar, guru menutup pembelajaran dengan do'a.

\section{Pertemuan Ketiga}

Kegiatan pendahuluan dilaksanakan dengan alokasi waktu 15 menit, diawali dengan guru memberi salam, guru mengajak peserta didik berdoa, guru melakukan absensi, guru mengecek tempat duduk peserta didik sudah rapi atau belum, lalu guru melakukan apersepsi.

Kegiatan inti yang dilakukan dengan alokasi waktu 90 menit, diawali dengan guru memberitahukan materi pelajaran yang akan dibahas. namun sekali lagi guru tidak menyampaikan tujuan pembelajaran yang akan disampaikan. Guru menayangkan gambar/foto tentang Sel. Peserta didik mengamati dengan seksama gambar/foto presentasi yang disajikan dan mencoba menginterprestasikannya. Berdasarkan hasil pengamatan terhadap gambar, peserta didik diminta untuk mendiskusikan tentang hal-hal yang ingin diketahui. Kemudian Peserta didik mempresentasikan hasil diskusi kelompok secara klasikal. Peserta didik mengemukakan pendapat atas presentasi yang dilakukan dan ditanggapi oleh kelompok yang mempresentasikan. Peserta didik bertanya atas presentasi yang dilakukan dan peserta didik lain diberi kesempatan untuk menjawabnya. Peserta didik menyimpulkan tentang poin-poin penting yang muncul dalam kegiatan pembelajaran yang baru dilakukan berupa : Laporan hasil pengamatan secara tertulis. Peserta didik menjawab pertanyaan yang terdapat pada buku pegangan peserta didik atau lembar kerja yang telah disediakan. Kegiatan penutup dilakukan dengan alokasi waktu 15 menit yaitu guru dan peserta didik menarik kesimpulan hasil pembelajaran yang telah 
dilaksanakan, guru memberikan soal evaluasi untuk mengukur keberhasilan belajar, guru menutup pembelajaran dengan do'a.

\section{c. Observasi (Observation)}

Pada siklus I, setelah peneliti selesai melakukan kegiatan pembelajaran, selanjutnya menguji kemampuan peserta didik untuk mendapatkan hasil belajar yang dengan melakukan posttest. Hasil evaluasi yang sudah diperoleh selanjutnya dianalisa untuk mengetahui berapa besar tingkat keberhasilan pembelajaran yang dilaksanakan pada siklus I dengan Kriteria Ketuntasan Minimal (KKM) 70.

\section{Tabel 1.}

Hasil Distribusi Frekuensi Hasil Posttestt Peserta didik Siklus I

\begin{tabular}{cccc}
\hline No & Interval & Frekuensi & Persentase (\%) \\
\hline 1 & $88-95$ & 9 & 21,95 \\
2 & $80-87$ & 10 & 24,39 \\
3 & $72-79$ & 5 & 12,19 \\
4 & $66-71$ & 2 & 4,89 \\
5 & $56-65$ & 8 & 19,51 \\
6 & $50-57$ & 7 & 17,07 \\
Jumlah & $\mathbf{4 1}$ & $\mathbf{1 0 0}$ \\
\hline
\end{tabular}

Sumber: Peneliti 2017

Berdasarkan tabel 1 dapat diuraikan bahwa hasil belajar peserta didik posttest diperoleh 7 peserta didik berada pada interval $50-57$ (21,95\%), 8 peserta didik berada pada interval $58-65(24,39 \%), 2$ peserta didik berada pada interval $66-71(4,89 \%), 5$ peserta didik berada pada interval $72-79(12,19 \%), 10$ peserta didik berada pada interval $80-87(24,39 \%), 9$ peserta didik berada pada interval $88-95(21,95 \%)$. Dengan nilai yang tertinggi 95. Sedangkan nilai yang terendah ialah 50. Untuk lebih jelasnya data frekuensi ulangan harian dapat ditunjukkan dengan diagram pada gambar 1 berikut ini:

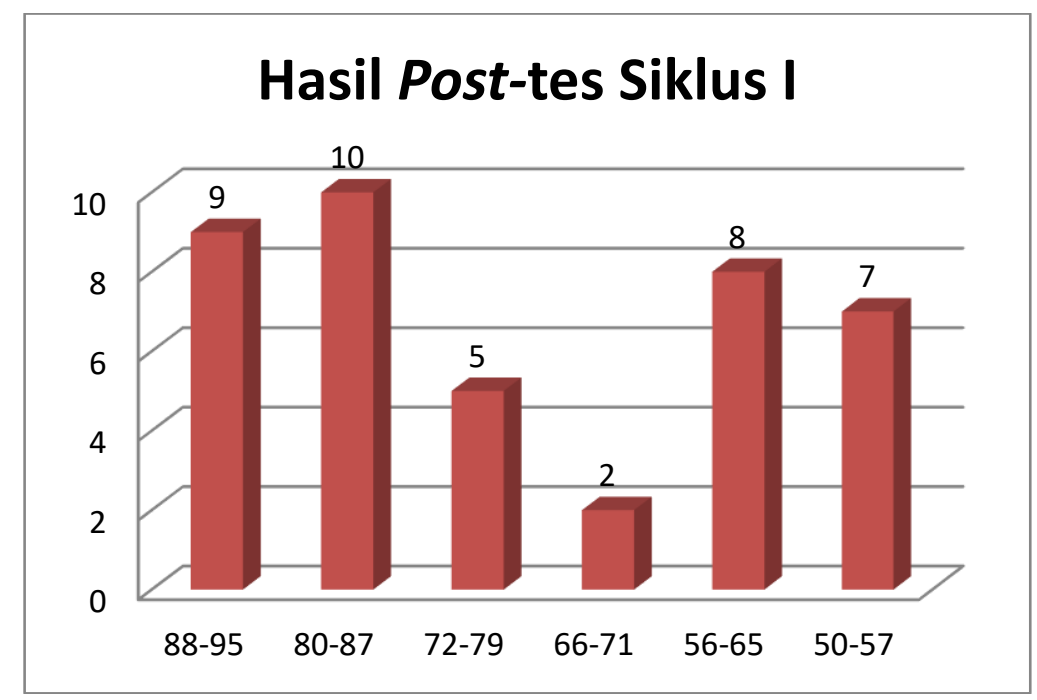

Sumber: Peneliti 2017

Gambar 1.

Diagram Hasil Posttest Siklus I 
Selain didapatkan frekuensi hasil posttest peserta didik didapatkan juga data ketuntasan belajar dari peserta didik. Berikut ini merupakan data ketuntasan posttes peserta didik pada Siklus I yang sudah disederhanakan kedalam tabel distribusi ketuntasan belajar:

Tabel 2.

Distribusi Ketuntasan Belajar Peserta didik Siklus I

\begin{tabular}{cccc}
\hline No & Ketuntasan & Jumlah & Presentase \\
\hline 1 & Tuntas $(\geq$ KKM 70) & 26 & 63,41 \\
2 & Belum Tuntas (<KKM 70) & 15 & 36,58 \\
Rata-rata & & 73,78 & \\
Skor Maksimal & & 95 & \\
Skor Minimum & \multicolumn{2}{c}{50} & \\
\hline Sumber: Peneliti 2017 & &
\end{tabular}

Berdasarkan tabel 2 tampak perbandingan peserta didik yang telah mencapai ketuntasan belajar $(K K M \geq 70)$ ialah 26 peserta didik $(63,41 \%)$ sedangkan peserta didik yang belum mencapai ketuntasan sebanyak 15 peserta didik $(36,58 \%)$. Dengan nilai tertinggi 95 dan nilai terendah ialah 50. Untuk lebih jelasnya data nilai ketuntasan belajar peserta didik Posttest pada tabel 2 dapat ditunjukkan dengan diagram seperti pada gambar 2 berikut ini:

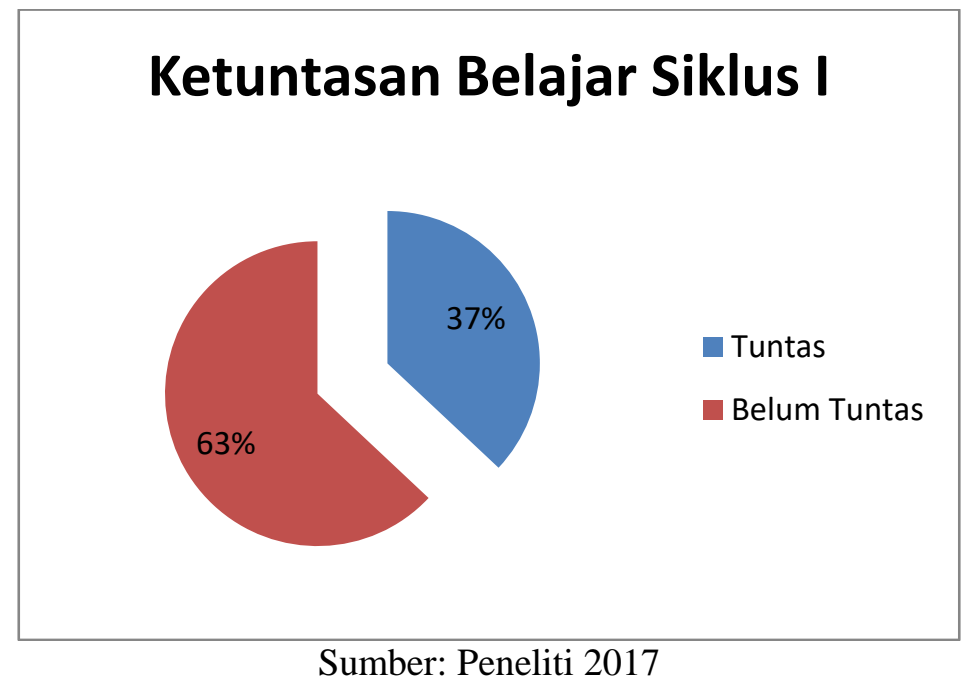

Gambar 2.

Diagram Ketuntasan Belajar pada Posttest Peserta didik Siklus I

\section{d. Refleksi (Reflection)}

Tahap refleksi ini bertujuan untuk mengatasi kekurangan yang terjadi pada siklus I, nantinya tidak akan terjadi di siklus II. Beberapa permasalahan di siklus I ialah sebagai berikut:

1. Diawal pembelajaran guru tidak menyampaikan tujuan pembelajaran.

2. Peserta didik hanya terfokus pada satu hal yang dilakukan, yang tidak membuat peserta didik mendengarkan instruksi dari guru.

3. Peserta didik seringkali mengobrol dengan teman sekelompoknya, biasanya hanya melihat temannya yang sedang mengerjakan tidak membantu berdiskusi.

Berdasarkan dari permasalahan yang telah diuraikan, dapat dilihat bahwa pada siklus I masih mempunyai permasalahan dikegiatan pembelajaran yang 
sedang berlangsung, diantaranya Guru tidak menyampaikan tujuan pembelajaran, peserta didik cenderung mengobrol sendiri saat guru menjelaskan materi, itu penyebabnya hasil belajar peserta didik masih rendah di bawah $(K K M \geq 70)$ yang telah ditentukan. Berdasarkan evaluasi hasil belajar tedapat 26 peserta didik dari 41 peserta didik yang hasil belajarnya telah mencapai KKM yang ditentukan, sedangkan yang 15 peserta didik yang lainnya dinyatakan belum mencapai KKM yang telah di tentukan. Dengan demikian, perlu dilakukan perbaikan guna mencapai hasil pembelajaran yang lebih baik dengan melaksanakan pembelajaran Siklus II.

\section{Siklus II}

Tindakan perbaikan pembelajaran pada siklus II dilaksanakan dalam 4 tahap yaitu tahap perencanaan, tindakan, pengamatan, dan refleksi.

\section{a. Perencanaan (Planning)}

Kegiatan perencanaan siklus II ini dimulai dengan memperhatikan kekurangan atau permasalahan dalam pelaksanaan pembelajaran pada siklus I, kekurangan tersebut nantinya akan menjadi dasar dalam perencanaan siklus II agar pelaksanaan tindakan siklus II ini menjadi lebih baik.

Berangkat dari permasalahan yang dijumpai tersebut maka peneliti menyiapkan teknik untuk memperbaiki hasil belajar peserta didik kelas. Persiapan yang dilakukan oleh peneliti ialah sebagai berikut:

1. Mengidentifikasi masalah yang ada dengan berbagai pihak untuk mencari pemecahan masalah untuk mendapatkan hasil yang lebih baik.

2. Penyusunan rencana pelaksanaan pembelajaran siklus I sesuai dengan model pembelajaran Discovery Learning yang digunakan dalam penelitian.

3. Menyiapkan alat peraga yang diperlukan saat pelaksanaan pembelajaran.

4. Penyusunan lembar instrumen observasi yang digunakan peneliti sebagai acuan dalam mengamati pencapaian dalam mengajar maupun dalam kegiatan pembelajaran.

5. Penyusunan instrumen penilaian sebagai acauan untuk menilai hasil belajar yang dilakukan oleh peserta didik.

Peneliti melakukan bertemu dengan kolaborator untuk mendiskusikan tentang kegiatan yang akan dilakukan oleh peneliti dan guru saat melakukan tindakan. Sebelum itu peneliti memaparkan masalah-masalah yang terjadi pada pelaksanaan tindakan di siklus I kepada guru, agar guru memberikan masukan dalam pelaksanaan tindakan di siklus II kepada peneliti, karena dengan masukan dari guru tersebut dapat memantapkan peneliti dalam menerapkan model pembelajaran Discovery Learning pada siklus II ini. Selain itu peneliti dengan kolaborator juga saling berbagi pendapat tentang penyusunan rencana pelaksanaan pembelajaran dan juga tindakan apa saja yang perlu dilakukan agar hasil pelaksanaan pembelajaran siklus II menjadi lebih baik dari siklus I.

\section{b. Pelaksanaan (Action)}

Kegiatan pelaksanaan pada siklus II ini dilaksanakan sebanyak 3 (tiga) kali pertemuan

\section{Pertemuan Pertama}

Kegiatan pendahuluan dilaksanakan dengan alokasi waktu 15 menit, diawali dengan guru memberi salam, guru mengajak peserta didik berdoa, guru melakukan absensi, guru mengecek tempat duduk peserta didik sudah rapi atau 
belum, guru melakukan apersepsi dengan bernyanyi bersama, guru menyampaikan tujuan pembelajaran yang akan disampaikan.

Kegiatan inti dilakukan dengan alokasi waktu 90 menit, Guru memberitahukan materi pelajaran yang akan dibahas. Guru memberitahukan kompetensi inti, kompetensi dasar, indikator, dan KKM pada pertemuan yang berlangsung. Guru menayangkan gambar/foto tentang Sel. Peserta didik mengamati dengan seksama gambar/foto presentasi yang disajikan dan mencoba menginterprestasikannya. Berdasarkan hasil pengamatannya terhadap gambar, peserta didik diminta untuk mendiskusikan tentang hal-hal yang ingin diketahui. Peserta didik menyampaikan hasil diskusi berupa kesimpulan berdasarkan hasil analisis secara lisan, tertulis, atau media lainnya. Kegiatan penutup dilakukan dengan alokasi waktu 15 menit, dengan menarik kesimpulan hasil pembelajaran yang telah dilaksanakan dan menutup pembelajaran dengan do'a.

\section{Pertemuan Kedua}

Kegiatan pendahuluan dilaksanakan dengan alokasi waktu 15 menit, diawali dengan guru memberi salam, guru mengajak peserta didik berdoa, guru melakukan absensi, guru mengecek tempat duduk peserta didik sudah rapi atau belum, guru melakukan apersepsi, dan guru menyampaikan tujuan pembelajaran yang akan disampaikan.

Kegiatan inti dilakukan dengan alokasi waktu 90 menit, Guru mengajukan beberapa pertanyaan kepada peserta didik misalnya apakah masih ingat dengan pembelajaran kemarin, guru mengulas kembali pembelajaran sebelumnya, peserta didik bersama-sama mengamati dengan seksama presentasi materi Sel dalam bentuk video presentasi yang disajikan secara langsung di depan kelas dan mencoba menginterprestasikannya, Peserta didik dan guru secara bersama-sama membahas presentasi project peserta didik, Peserta didik mengkomunikasikan secara lisan atau mempresentasikan materi dengan rasa percaya diri sesuai dengan pemahamannya, mempresentasikan hasil diskusi kelompok secara klasikal, mengemukakan pendapat atas presentasi yang dilakukan dan ditanggapi oleh kelompok yang mempresentasikan, menjawab pertanyaan tentang project yang di presentasikan, bertanya tentang hal yang belum dipahami, atau guru melemparkan beberapa pertanyaan. Kegiatan penutup dilakukan selama 15 menit yaitu guru dan peserta didik menarik kesimpulan hasil pembelajaran yang telah dilaksanakan, guru memberikan soal evaluasi untuk mengukur keberhasilan belajar, guru menutup pembelajaran dengan do'a.

\section{Pertemuan Ketiga}

Kegiatan pendahuluan dilaksanakan dengan alokasi waktu selama 15 menit, diawali dengan guru memberi salam, guru mengajak peserta didik berdoa, guru melakukan absensi, guru mengecek tempat duduk peserta didik sudah rapi atau belum, guru melakukan apersepsi, dan guru menyampaikan tujuan pembelajaran.

Kegiatan inti dilaksanakan selama 90 menit, guru mengajukan beberapa pertanyaan kepada peserta didik misalnya apakah masih ingat dengan pembelajaran kemarin, guru mengulas kembali pembelajaran sebelumnya, guru menayangkan gambar/foto hasil presentasi tugas project karya peserta didik, Peserta didik mengamati dengan seksama presentasi project karya dalam bentuk gambar/foto presentasi yang disajikan dan mencoba menginterprestasikannya, 
guru memberikan kembali secara ringkas materi Sel, kemudian peserta didik melakukan Eksperimen/explorer: peserta didik melakukan percobaan mengamati sel tumbuhan berdasarkan langkah-langkah pada LKS dan menuliskan data hasil pengamatan, guru memberikan kesempatan pada peserta didik untuk mengidentifikasi sebanyak mungkin pertanyaan yang berkaitan dengan gambar yang disajikan, peserta didik dalam kelompoknya berdiskusi, peserta didik mengerjakan beberapa soal mengenai materi Sel. Peserta didik menyampaikan hasil diskusi berupa kesimpulan berdasarkan hasil analisis secara lisan, tertulis atau media lainnya, peserta didik bertanya atas presentasi yang dilakukan dan peserta didik lain diberi kesempatan untuk menjawabnya. Kegiatan penutup dilakukan selama 15 menit, yaitu guru dan peserta didik menarik kesimpulan hasil pembelajaran yang telah dilaksanakan, guru memberikan soal evaluasi untuk mengukur keberhasilan belajar, kemudian guru menutup pembelajaran dengan do'a.

\section{c. Observasi (Observation)}

Hasil belajar yang telah dianalisa oleh peneliti menunjukan hasil yang sangat memuaskan pada siklus II ini karena semua peserta didik kelas VII-6 telah mencapai KKM yang sudah ditentukan. Hasil belajar dari soal Posttest yang telah dikerjakan peserta didik dapat dilihat pada tabel yang disajikan berikut ini:

Tabel 3.

Hasil Distribusi Frekuensi Hasil Posttestt Peserta didik Siklus II

\begin{tabular}{|c|c|c|c|}
\hline No & Interval & Frekuensi & Persentase (\%) \\
\hline 1 & $88-94$ & 14 & 34,14 \\
\hline 2 & $82-87$ & 8 & 19,52 \\
\hline 3 & $75-81$ & 9 & 21,95 \\
\hline 4 & $68-74$ & 4 & 9,76 \\
\hline 5 & $62-67$ & 0 & - \\
\hline 6 & $55-61$ & 6 & 14,63 \\
\hline \multicolumn{2}{|c|}{ Jumlah } & 41 & 100 \\
\hline
\end{tabular}

Sumber: Peneliti 2017

Berdasarkan tabel 3 dapat diuraikan hasil posttest sebagai berikut : diperoleh 6 peserta didik berada pada interval $55-61(14,63 \%), 0$ atau tidak ada peserta didik berada pada interval 62 - $67(0 \%), 4$ peserta didik berada pada interval 68 $74(9,76 \%), 9$ peserta didik berada pada interval $75-81(21,95 \%), 8$ peserta didik berada pada interval $82-87(19,52 \%), 14$ peserta didik berada pada interval 88 $94(34,14 \%)$. Dengan nilai yang tertinggi ialah 94 . Sedangkan nilai yang terendah ialah 55. Untuk lebih jelasnya data distribusi fekuensi hasil posttest dapat ditunjukkan dengan diagram seperti pada gambar 3 berikut ini : 


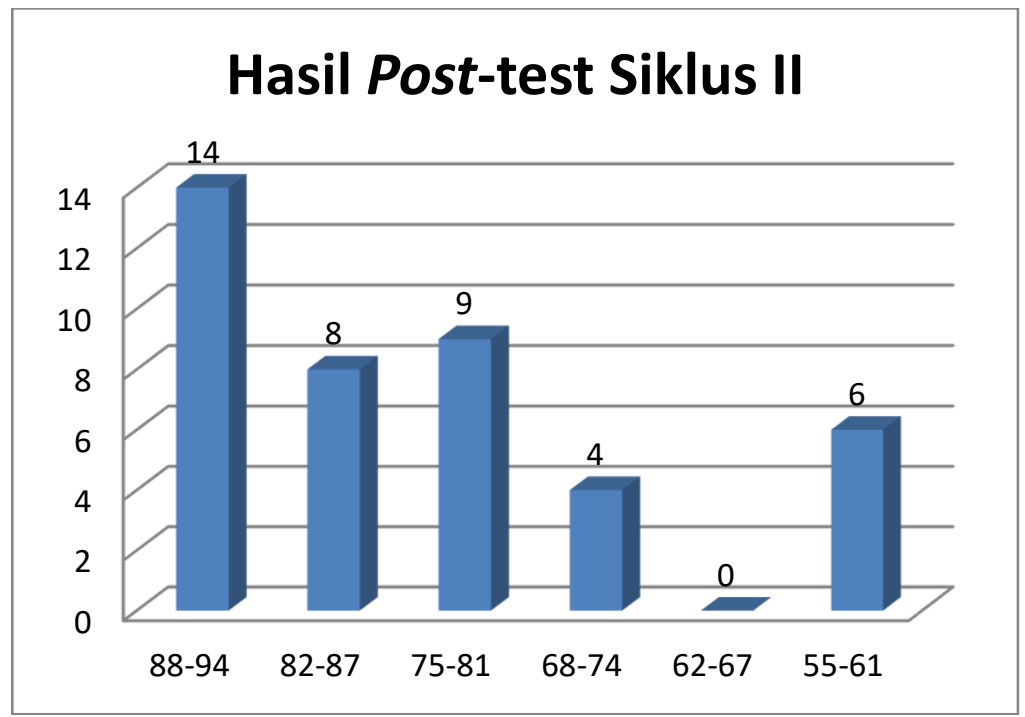

Sumber: Peneliti 2017

Gambar 3.

Diagram Hasil Posttest Peserta didik Siklus II

Selain didapatkan frekuensi hasil posttest peserta didik didapatkan juga data ketuntasan belajar dari peserta didik. Berikut ini merupakan data ketuntasan posttest peserta didik pada siklus II yang sudah disederhanakan kedalam tabel distribusi ketuntasan belajar:

Tabel 4.

Distribusi Ketuntasan Belajar Peserta didik Siklus II

\begin{tabular}{cccc}
\hline No & Ketuntasan & Jumlah & Presentase \\
\hline 1 & Tuntas $(\geq$ KKM 70) & 35 & 85,36 \\
2 & Belum Tuntas $(<$ KKM 70) & 6 & 14,63 \\
Rata-rata & & 80,36 & \\
Skor Maksimal & & 94 & \\
Skor Minimum & \multicolumn{2}{c}{55} & \\
\hline
\end{tabular}

Sumber: Peneliti 2017

Berdasarkan tabel 4 tampak bahwa 35 peserta didik kelas VII-6 telah mencapai ketuntasan belajar $(\mathrm{KKM} \geq 70)$ Dengan nilai tertinggi ialah 94 sedangkan nilai terendah ialah 55. Untuk lebih jelasnya data nilai ketuntasan belajar pada posttest peserta didik siklus II pada tabel dapat ditunjukan dengan diagram seperti pada gambar 4 berikut ini: 


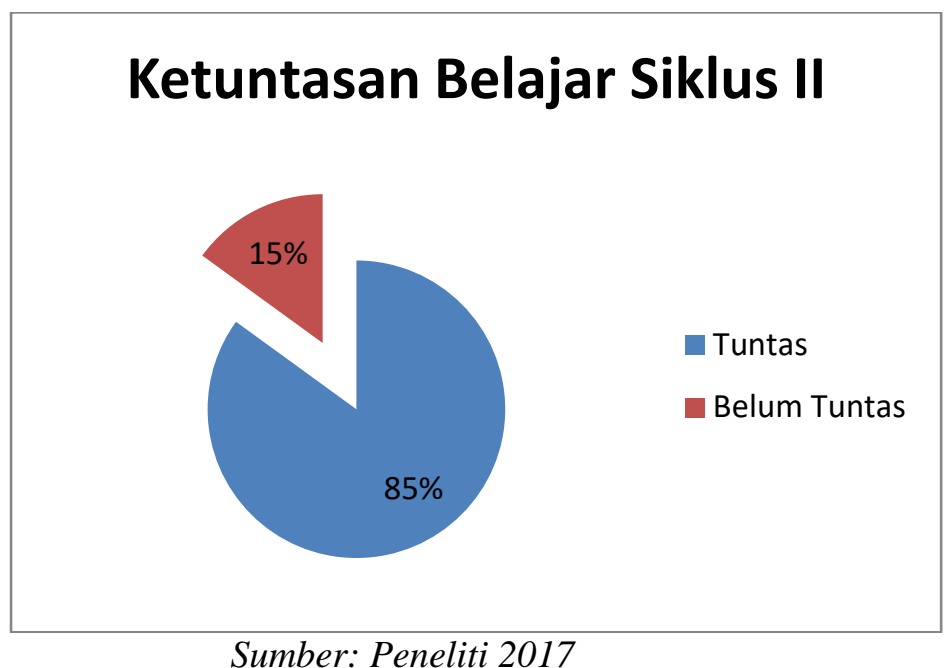

Gambar 4.

Diagram Ketuntasan Belajar pada Posttest Peserta didik Siklus II

\section{d. Refleksi (Reflection)}

Pada siklus II ini pelaksanaan pendekatan pembelajaran pada peserta didik secara keseluruhan sudah sangat baik karena dalam proses pembelajaran guru mampu menguasai sekaligus menerapkan model Discovery Learning dengan sangat baik sehingga aktivitas belajar peserta didik menjadi lebih meningkat dari sebelumnya dan berpengaruh pada hasil belajar peserta didik yang dapat dilihat dari hasil evaluasi peserta didik yang dilaksanakan pada akhir kegiatan siklus II bahwa 35 peserta didik atau $85 \%$ peserta didik telah mencapai ketuntasan belajar yang sudah ditentukan yaitu KKM $\geq 70$. Walaupun pada siklus ini secara keseluruhan pelaksanaan sudah baik masih saja terdapat hal yang mengganggu yaitu masalah tentang peserta didik yang masih mengobrol di dalam kelas, tetapi berdasarkan siklus I yang telah dilakukan maka permasalahan yang ada dapat diatasi pada siklus II ini yaitu dengan cara menegur peserta didik yang sedang mengobrol saat pembelajaran berlangsung dan menasihatinya secara baik.

\section{Discussion}

Dengan penerapan model pembelajaran Discovery Learning, diharapkan dapat meningkatkan hasil belajar. Tidak hanya hasil belajar peserta didik saja yang meningkat, namun sikap peserta didik dalam mengikuti pembelajaran juga meningkat. Setelah dilakukan penelitian peserta didik menjadi lebih aktif selama mengikuti pembelajaran. Sebelum ada penelitian beberapa peserta didik saja yang aktif dalam pembelajaran. Priyatni (2014:106) menyatakan tujuan penggunaan pembelajaran penemuan adalah untuk menemukan konsep atau prinsip yang belum diketahui oleh peserta didik.

Temuan keefektifan dalam pembelajaran Discovery Learning merupakan kontribusi sintaks pembelajaran Discovery Learning. Langkah-langkah pembelajaran Discovery Learning memancing peserta didik untuk aktif. Hal ini dikarenakan karena pada pembelajaran ini: (1) Mengembangkan cara belajar peserta didik aktif; (2) Menemukan dan menyelidiki sendiri konsep yang dipelajari, maka hasil yang diperoleh akan tahan lama dalam ingatan dan tidak mudah dilupakan; (3) Pemhamana yang ditemukan sendiri merupakan pemhaman yang betul-betul dikuasai dan mudah ditransfer dalam situasi lain; (4) Peserta didik belajar menguasai salah satu metode ilmiah yang akan dapat dikembangkan sendiri; (5) peserta didik belajar berpikir analisis dan mencoba 
memecahkan permasalahan yang dihadapi sendiri, dan kebiasaan baik ini akan diterapkan dalam kehidupan nyata.

Setiap model pembelajaran tentunya memiliki keunggulan dan kekurangan masingmasing. Beberapa keunggulan model pembelajaran Discovery Learning juga diungkapkan oleh Hosnan (2016: 287-288) sebagai berikut : (1) Membantu peserta didik untuk mengoptimalkan kemampuan baik dari segi kognitif maupun dari segi keterampilan, (2) Pengetahuan yang diperoleh setiap peserta didik akan bertahan lama, karena mereka memperolehnya dengan pengalaman secara langsung, (3) Membantu dan meningkatkan kemampuan setiap peserta didik dalam memecahkan masalah. (4) Memperkuat konsep diri, karena setiap peserta didik diberikan kesempatan dan kepercayaan untuk bekerja sama dengan lainnya, (5) Mendorong setiap peserta didik untuk lebih aktif dalam mencari informasi dan ilmu pengetahuan, (6) Mengajak peserta didik untuk berpikir dan merumuskan pendapatan sementara atau hipotesis sendiri, (7) Melatih setiap peserta didik untuk belajar secara mandiri, dan (8) Peserta didik akan menjadi lebih aktif karena menggunakan kemampuannya sendiri dalam menemukan hasil akhir.

Pembelajaran Discovery Learning juga tak lepas dari beberapa kelemahan. Hosnan (2016: 288 - 289) menyatakan setidaknya ada 3 (tiga) kekurangan atau kelemahan dari penggunaan model Discovery Learning ini, yaitu : (1) Menghabiskan waktu, karena guru harus menjadi fasilitator, motivator dan sekaligus pembimbing, (2) Tidak semua peserta didik memiliki kemampuan berpikir rasional karena belum terbiasa, dan (3) Tidak semua peserta didik dapat mengikuti model pembelajaran ini karena alasan tertentu. Model pembelajaran ini diharapkan berguna untuk menumbuhkan kerjasama, kreatif, berpikir kritis dalam pembelajaran. Jadi model pembelajaran Discovery Learning yang digunakan peneliti berhasil meningkatkan hasil belajar peserta didik karena sudah sesuai dengan sintak pembelajarannya.

\section{CONCLUSION}

\section{Simpulan}

Berdasarkan hasil dan pembahasan penelitian, dapat ditarik simpulan bahwa pembelajaran IPA dengan menggunakan model pembelajaran Discovery Learning atau pembelajaran terbimbing dapat meningkatkan hasil belajar peserta didik. Hal ini dibuktikan melalui peningkatan persentase peserta didik yang mencapai ketuntasan belajar. Kemudian setelah melakukan kegiatan siklus II, peserta didik mengalami perubahan perilaku yang awalnya pasif menjadi aktif dan percaya diri.

\section{Saran}

1. Bagi sekolah sebagai lembaga yang dapat menciptakan mutu pendidikan, diharapkan dapat mengaktifkaan peserta didik dalam pembelajaran yang menyenangkan dalam proses belajar mengajar sehingga hasil belajar dapat tercapai secara maksimal.

2. Bagi Guru, disarankan untuk melaksanakan pembelajaran dengan metode dan model yang kreatif dan inovatif, yang melibatkan peserta didik dalam proses pembelajaran yang bermakna. Metode yang dipilih diharapkan dapat menumbuhkan rasa keingintahuan peserta didik dan menumbuhkan keaktifan peserta didik dalam proses pembelajaran yang akan meningkatkan hasil belajar.

3. Bagi Peserta didik yang telah mencapai hasil belajar yang baik agar dapat mempertahankan dan meningkatkan hasil belajarnya dan dapat membantu temanteman yang lainnya. Bagi peserta didik yang hasil belajarnya masih belum mencapai kriteria ketuntasan agar dapat meningkatkan hasil belajarnya. 


\section{REFERENCES}

Abdurrahman, Mulyono. (2015). Pendidikan Bagi Anak Berkesulitan Belajar. Jakarta: Rineka Cipta

Angkowo R. dan A. Kosasih. (2007). Optimalisasi Media Pembelajaran. Jakarta : PT. Grasindo

Budiningsih, Asri. (2012). Belajar dan Pembelajaran. Jakarta: Rineka Cipta.

Hosnan, M. (2016). Pendekatan Saintifik dan Kontekstual dalam Pembelajaran Abad 21. Kunci Sukses Implementasi Kurikulum 2013. Bogor: Ghalia Indonesia.

Markaban, (2008). Model Pembelajaran Matematika dengan Pendekatan Penemuan Terbimbing. Yogyakarta : Departemen Pendidikan Nasional PPPG Matematika.

Priyatni, Endah Tri. 2014. Desain Pembelajaran Bahasa Indonesia dalam Kurikulum 2013. Jakarta: Bumi Aksara.

Slameto. (2010). Belajar dan faktor-faktor yang mempengaruhinya. Jakarta: Rineka Cipta Suprihatiningrum, Jamil. (2016). Strategi Pembelajaran. Jogjakarta: Ar-Ruzz Media.

Suryosubroto. (2010). Manajemen Pendidikan Di Sekolah. Jakarta:Rineka Cipta W.S. Winkel. (2014). Psikologi Pengajaran. Yogyakarta: Media Abadi.

Vhalery, R. (2019). PERBANDINGAN AKTIVITAS BELAJAR MELALUI MODEL PEMBELAJARAN KOOPERATIF TIPE GROUP INVESTIGATION DAN NUMBERED HEAD TOGETHER. Research and Development Journal of Education, 6(1), 80-93. 